\title{
EFFECTIVENESS OF ANTIDIARRHEAL UNRIPE WOODEN BANANA (Musa paradisiaca L.) IN MALE Balb-C/MICE INDUCED WITH Escherichia coli
}

\author{
Arista Wahyu Ningsih ${ }^{1}$, Maftuchah Rochmanti ${ }^{2}$, Achmad Basori ${ }^{2}$ \\ ${ }^{1}$ Master Program of Basic Medical Science, Faculty of Medicine, ${ }^{2}$ Department of Pharmacology, Faculty of \\ Medicine, Universitas Airlangga, Surabaya, Indonesia
}

ABSTRACT

The survey results in Indonesia in 2017 showed that the diarrhea morbidity rate for all age groups was 6.897.463. In Indonesia, unripe wooden banana has been used empirically as an antidiarrheal by the people in Senduro village, Lumajang, East Java. The study aimed to prove the antidiarrheal effect of ethanol extract of unripe wooden banana (Musa paradisiaca L.) in male Balb-C/mice induced by Escherichia coli bacteria. This study was a laboratory experimental study with post-test only control group design that used 40 mice divided into 8 groups, namely 1 group without treatment (normal mice) and 7 groups induced by Escherichia coli (1 negative control group given CMC-Na, 3 groups positive controls were given Loperamid HCL $0,5 \mathrm{mg} / \mathrm{kgBW}, 1 \mathrm{mg} / \mathrm{kgBW}$ and $2 \mathrm{mg} / \mathrm{kgBW}$ and 3 treatment groups were given extracts $100 \mathrm{mg} / \mathrm{kgBW}, 200 \mathrm{mg} / \mathrm{kg} B W$ and 400 $\mathrm{mg} / \mathrm{kg} B W$ ). Observation of animals in this study was carried out for 4 hours. Data were analyzed of frequency of diarrhea, fecal weight and fecal consistency used Kruskal Wallis and the results showed significant differences between treatment groups $(p<0.05)$. From the results of the Mann-Whitney test, the ethanol extract of unripe wooden banana with a dose of 100 $\mathrm{mg} / \mathrm{kgBW}$ was not significantly different ( $p>0.05$ ) with the control group of Loperamid HCL dose of $0.5 \mathrm{mg} / \mathrm{kgBW}$. Unripe wooden banana had been shown to have antidiarrheal activity at an extract dose of $100 \mathrm{mg} / \mathrm{kg} B W$ in terms of the parameters of fecal consistency, frequency of diarrhea, and fecal weight. The results showed that the higher the dose, the better antidiarrheal activity.

Keywords: Unripe wooden banana; antidiarrheal effect

\section{ABSTRAK}

Hasil survey di Indonesia pada tahun 2017 menunjukkan bahwa angka kesakitan diare untuk seluruh golongan umur adalah 6.897.463 jiwa. Di Indonesia, pisang kayu mentah telah digunakan secara empiris sebagai antidiare oleh masyarakat Senduro, Lumajang, Jawa Timur. Penelitian ini bertujuan untuk membuktikan adanya efek antidiare ekstrak etanol pisang kayu mentah (Musa paradisiaca L.) pada mencit jantan Galur Balb-C yang diinduksi bakteri Escherichia coli. Penelitian ini merupakan penelitian eksperimental laboratorium post-test only control group design dengan 40 mencit yang terbagi dalam 8 kelompok, yaitu 1 kelompok tanpa perlakuan (mencit normal) dan 7 kelompok diinduksi bakteri Escherichia coli (1 kelompok kontrol negatif diberi CMC-Na, 3 kelompok kontrol positif diberi Loperamid HCL $0.5 \mathrm{mg} / \mathrm{kgBB}, 1 \mathrm{mg} / \mathrm{kgBB}, 2 \mathrm{mg} / \mathrm{kgBB}$ dan 3 kelompok perlakuan diberi ekstrak bahan uji dosis $100 \mathrm{mg} / \mathrm{kg} \mathrm{BB,200} \mathrm{mg/kg} \mathrm{BB} \mathrm{dan} 400 \mathrm{mg} / \mathrm{kg}$ BB). Pengamatan hewan coba pada penelitian ini dilakukan selama 4 jam. Analisis data frekuensi diare, bobot feses dan konsistensi feses menggunakan Kruskal Wallis dan hasilnya menunjukkan perbedaan signifikan antar kelompok perlakuan $(p<0,05)$. Hasil uji Mann-Whitney, ekstrak buah pisang kayu mentah tidak berbeda signifikan $(p>0.05)$ dengan Loperamid HCL 0,5 mg/kgBB. Buah pisang kayu mentah terbukti memiliki aktivitas antidiare pada dosis ekstrak $200 \mathrm{mg} / \mathrm{kg}$ BB ditinjau dari parameter konsistensi feses. Hasil penelitian menunjukkan semakin tinggi dosis maka aktifitas antidiare semakin bagus.

Kata kunci: Pisang kayu mentah; efek antidiare

Correspondence: Maftuchah Rochmanti, Department of Pharmacology, Faculty of Medicine, Universitas Airlangga, Indonesia. E-mail: maftuchah-r@fk.unair.ac.id

\section{pISSN:2355-8393 • eISSN: 2599-056x • doi:}

- Fol Med Indones. 2020;56:208-215 • Received 2 Aug $2019 \bullet$ Accepted 13 Feb 2020

- Open access under CC-BY-NC-SA license • Available at https://e-journal.unair.ac.id/FMI/

\section{INTRODUCTION}

Diarrhea was a disease that often causes extraordinary dealings. Diarrhea occupies a high position in the list of diseases that cause death in several developing countries. The survey results in Indonesia in 2017 showed that the diarrhea morbidity rate for all age groups ranged from 6.897 .463 people. In West Java province, diarrheal disease get the first rank with morbidity of $1,261,159$ people. In East Java province, 
diarrheal disease is the second rank with morbidity of $1,048,885$ people. Diarrhea is an endemic disease in Indonesia and also a potential extraordinary dealings disease which are often followed by death. In 2016 there were 3 times diarrhea outbreaks spread in 3 provinces, 3 district, with 198 people having diarrhea and 6 deaths (CFR 3,04\%), it was seen that the CFR at extraordinary events was still quite high because the CFR $>1 \%$. The incidence of national diarrhea according to the results of the 2014 diarrhea morbidity survey was 270/1000 population.

Diarrhea is a disease characterized by increasing frequency of defecation, accompanied by changes in fecal consistency to be more fluid or soft. One of the side effects of diarrhea is dehydration. When diarrhea occurs, it will loss of fluid and electrolytes, so that the body will become dehydrated. If the condition of dehydration is not treated immediately, it can cause death.

In Indonesia, unripe wooden banana (Musa paradisiaca $L$.) is a drug that is often used empirically by the Senduro village community, Lumajang, East Java, to treat diarrhea. Empirically, the use of unripe wooden bananas (Musa paradisiaca L.) in the Senduro is used by burning, steaming and boiling. In previous studies, the banana also had an antidiarrheal effect on mice induced by Oleum Ricini. The results of the Ningsih (2010) study also showed that the phytochemical test results of the ethanol extract of unripe wooden bananas (Musa paradisiaca L.) showed a positive content of tannin having antidiarrheal activity induced by Oleum Ricini at a dose of $100 \mathrm{mg} / \mathrm{kg} \mathrm{BW}$. The toxicity test of the raw ethanol extract of banana wood had never been done before, but Antonius and Eka tested the toxicity of banana peels in 2018. Results of the toxicity test Ethyl acetate extract of ambon banana peel showed an equivalent value of 146.78 ppm LC50 with $146.78 \mathrm{mg}$ in $1 \mathrm{~L}$ of distilled water.

The results of previous studies on mice that have been made diarrhea with induction of castor oil obtained that the ethanol extract of banana (Musa paradisiaca L.) raw dose of $100 \mathrm{mg} / \mathrm{kg}$ BW could reduce the frequency of defecation, the amount of soft or liquid fecal and fecal weight for 4 hours of observation in male mice which had been induced by castor oil. The use of unripe wooden banana (Musa paradisiaca L.) as a diarrhea drug induced by the bacterium Escherichia coli had never been proven scientifically. In terms of etiology, diarrhea was classified as non-specific and specific diarrhea. Nonspecific diarrhea was diarrhea caused by chronic diseases, or the use of certain drugs. While specific diarrhea was diarrhea caused by bacterial, viral, and parasitic infections. Escherichia coli was one of the causes of diarrhea in humans. Escherichia coli causes diarrhea because the intestines produce toxins that irritate the intestinal membrane ( $\mathrm{Yu}$ et al 2017). In the preliminary test conducted by the researcher, the results of diarrhea induction dose were $2 \times 0.8 \mathrm{ml}$ of Escherichia coli bacterial suspension $2 \times 10^{8} \mathrm{cfu} / \mathrm{ml}$.

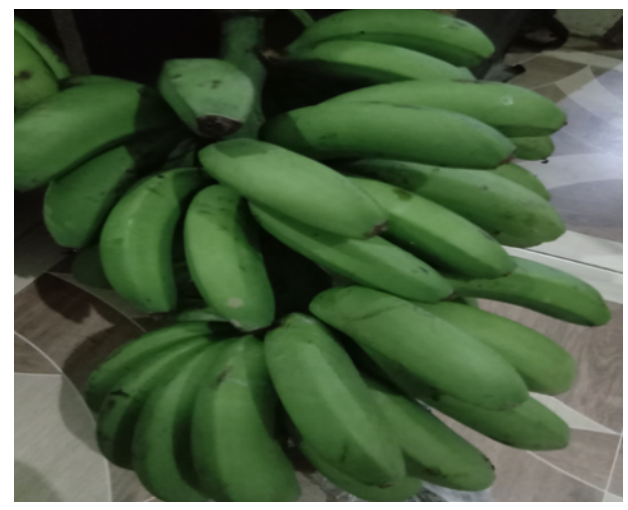

Fig. 1. Unripe wooden banana (Musa paradisiaca L.)

\section{MATERIALS AND METHODS}

This study had passed the ethical feasibility test on the health research ethics committee of the Faculty of Medicine, Universitas Airlangga, Surabaya, with number 64/EC/KEPK/FKUA/2019. This study used the ethanol extract of unripe wooden banana material (Musa paradisiaca L.), CMC-Na, Escherichia coli ATCC 25922 bacteria, filter paper, ethanol, distilled water in Loperamid HCL. The experimental animals used were male mice Balb-C strain with a weight of 20-30 grams with an average age of 2-3 months obtained from the STIKES Biomedical Laboratory Anwar Medika.

Making ethanol extract of unripe wooden banana (Musa paradisiaca $L$.) was carried out by means of extracted using 96\% ethanol using remaseration method 13 . The extract obtained was concentrated with a rotary evaporator, evaporated on a water bath and dried in a $60 \mathrm{oC}$ oven. The yield of ethanol extract of unripe wooden banana was $6.45 \%$.

The antidiarrheal effect of the ethanol extract unripe wooden banana (Musa paradisiaca L.) was tested by the method of diarrhea protection induced by Escherichia coli ATCC 25922 bacteria. Test animals were divided into 8 groups, each group consists of 4 mice, namely the control group, in this group were given no treatment. The negative control group induced Escherichia coli ATCC 25922 bacterial suspension. The comparison group 1 was given a Loperamid HCL $0.5 \mathrm{mg} / \mathrm{kg} \mathrm{BW}$ suspension. The comparison group 2 was given a Loperamid HCL $1 \mathrm{mg} / \mathrm{kg} \mathrm{BW}$ suspension. The 
comparison group 3 was given a Loperamid HCL 2 $\mathrm{mg} / \mathrm{kg}$ BW suspension. The first treatment group was given an ethanol extract of unripe wooden banana (Musa paradisiaca L.) $100 \mathrm{mg} / \mathrm{kg} \mathrm{BW}$. Treatment group 2 was given an ethanol extract suspension of unripe wooden banana (Musa paradisiaca L.) $200 \mathrm{mg} / \mathrm{kg} \mathrm{BW}$. Treatment group 3 was given an ethanol extract of unripe wooden banana (Musa paradisiaca L.) 400 $\mathrm{mg} / \mathrm{kg} \mathrm{BW}$. In this study which used 3 groups of doses of ethanol extract of unripe wooden banana and 3 groups of Loperamid HCL doses (positive control group) referred to previous studies conducted by Ningsih 2010. Data on frequency of defecation, fecal weight, and consistency of fecal observed in extract and group. The positive control groups were compared to the dose response curve to see the effectiveness of antidiarrheal (Ningsih 2010).

Mice were fasted for 1 hour before testing began. Mice were placed in a vessel on an observation filter paper which was first weighed. Mice induced bacterial suspense $2 \times 108 \mathrm{cfu} / \mathrm{ml}$ orally by 2 x $0.8 \mathrm{ml}$. One hour after treatment, each mouse was given an ethanol extract of unripe wooden banana (Musa paradisiaca L.) $100 \mathrm{mg} / \mathrm{kgBW}, 200 \mathrm{mg} / \mathrm{kgBW}, 400 \mathrm{mg} / \mathrm{kg} \mathrm{BW}$ and Loperamid HCL $0.5 \mathrm{mg} / \mathrm{kg} \mathrm{BW}, 1 \mathrm{mg} / \mathrm{kg} \mathrm{BW}$ and 2 $\mathrm{mg} / \mathrm{kgBW}$. The response that occurs in mice was observed an interval of 30 minutes for 4 hours. The parameters observed were frequency of defecation, fecal consistency and fecal weight.

\section{RESULTS}

\section{The result of extracting unripe wooden banana}

The extracts were calculated to show the number of chemical compounds from the unripe wooden banana extracted by the extract solution. The yield of unripe wooden banana extract yield can be seen in Table 1 .

\section{Results of phytochemical screening}

According to Dalimartha (2005) banana plants contained metabolites secondary to tannins, saponins, alkaloids, and flavonoids. Phytochemical screening was carried out to determine the secondary metabolite groups found in the ethanol extract of unripe wooden banana. Phytochemical screening was carried out by examining the compounds of tannins, alkaloids, saponins, and flavonoids14. The results of phytochemical screening extract from unripe wooden banana (Musa paradisiaca L.) can be seen in Table 2.

Table 1. Results of ethanol extraction of unripe wooden banana (Musa paradisiaca L.)

\begin{tabular}{cccc}
\hline Plan part & $\begin{array}{c}\text { Powder } \\
\text { weight }(\mathrm{g})\end{array}$ & $\begin{array}{c}\text { Weight of } \\
\text { extract }(\mathrm{g})\end{array}$ & $\begin{array}{c}\text { Rendemen } \\
(\% \mathrm{~b} / \mathrm{v})\end{array}$ \\
\hline $\begin{array}{c}\text { Unripe wooden banana }(\text { Musa } \\
\text { paradisiaca L) }\end{array}$ & 500 & 32.2701 & 6.45 \\
\hline
\end{tabular}

Table 2. Phytochemical screening results of ethanol extract of unripe wooden banana (Musa paradisiaca L.)

\begin{tabular}{clc}
\hline No & Phytochemical screening & Result \\
\hline 1 & Tanin & + \\
2 & Alkaloid & + \\
3 & Saponin & + \\
4 & Falvonoid & + \\
\hline \multicolumn{2}{l}{ Description: (+): there was (-): none }
\end{tabular}

Table 3. Data on average fecal weight of mice in each treatment group (gram)

\begin{tabular}{ccccccccc}
\hline Inducer & $\begin{array}{c}\text { Extract } \\
100\end{array}$ & $\begin{array}{c}\text { Extract } \\
200\end{array}$ & $\begin{array}{c}\text { Extract } \\
400\end{array}$ & $\begin{array}{c}\text { Extract } \\
0.5\end{array}$ & Lop 1 & Lop 2 & $\begin{array}{c}\text { Control } \\
\text { group }\end{array}$ & $\begin{array}{c}\text { Negative } \\
\text { control }\end{array}$ \\
\hline Escherichia & 0.8070 & 0.8548 & 0.4780 & 1.2239 & 0.1621 & 0.5217 & 0.3841 & 3.2059 \\
coli & 0.5737 & 0.9241 & 0.7806 & 1.1754 & 0.1834 & 0.1041 & 0.5462 & 2.3245 \\
& 0.7913 & 0.6086 & 0.9096 & 1.1546 & 0.2743 & 0.0639 & 0.5964 & 1.8674 \\
& 1.2949 & 1.1896 & 0.2914 & 0.8541 & 0.4154 & 0.1979 & 0.4801 & 2.0197 \\
& 1.0520 & 0.8581 & 0.6336 & 0.3765 & 0.4065 & 0.2097 & 0.3474 & 1.5826 \\
Average & 0,9038 & 0,8870 & 0,6186 & 0,9569 & 0,2883 & 0,2195 & 0,4708 & 2,2000 \\
\pm & \pm & \pm & \pm & \pm & \pm & \pm & \pm & \pm \\
SD & 0.276 & 0.208 & 0.249 & 0.356 & 0.119 & 0.179 & 0.105 & 0.623 \\
\hline
\end{tabular}




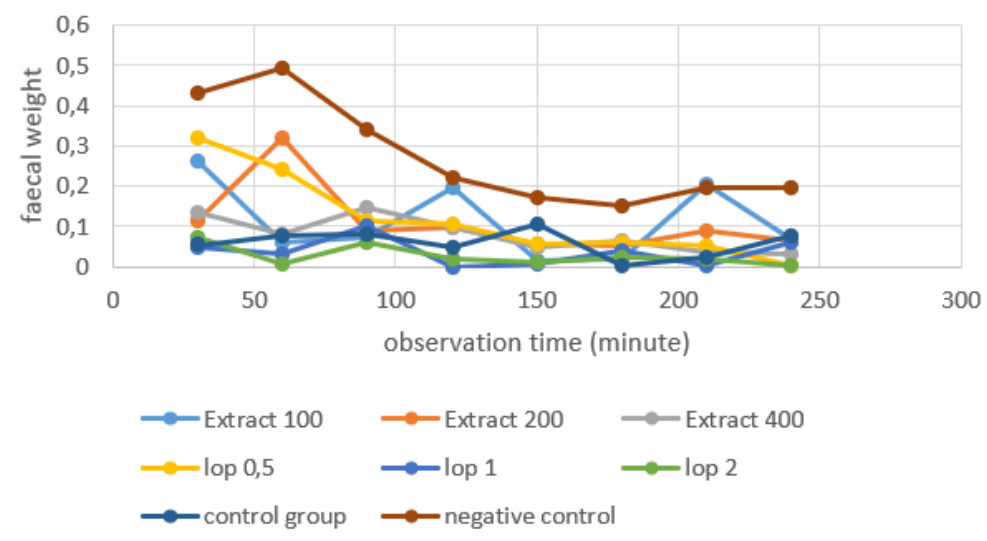

Fig. 2. Summary of the graph of the fecal weight average of each treatment group.

Table 4. Mann-Whitney test results in fecal weight between treatment groups

\begin{tabular}{|c|c|c|c|c|c|c|c|c|}
\hline & $\begin{array}{c}\text { Extract } \\
100\end{array}$ & $\begin{array}{c}\text { Extract } \\
200\end{array}$ & $\begin{array}{c}\text { Extract } \\
400\end{array}$ & Lop 0,5 & Lop1 & Lop 2 & Normal & $\mathrm{K}(-)$ \\
\hline Extract 100 & - & $\mathrm{TB}^{0.917}$ & $\mathrm{~TB}^{0.117}$ & $\mathrm{~TB}^{0.602}$ & $\mathrm{~B}^{0.009}$ & $\mathrm{~B}^{0.016}$ & $\mathrm{~B}^{0.028}$ & $\mathrm{~B}^{0.009}$ \\
\hline Extract 200 & $\mathrm{~TB}^{0.917}$ & - & $\mathrm{TB}^{0.175}$ & $\mathrm{~TB}^{0.347}$ & $\mathrm{~B}^{0.009}$ & $\mathrm{~B}^{0.009}$ & $\mathrm{~B}^{0.016}$ & $\mathrm{~B}^{0.009}$ \\
\hline Extract 400 & $\mathrm{~TB}^{0.117}$ & $\mathrm{~TB}^{0.175}$ & - & $\mathrm{TB}^{0.117}$ & $\mathrm{~B}^{0.028}$ & $\mathrm{~B}^{0.028}$ & $\mathrm{~TB}^{0.347}$ & $\mathrm{~B}^{0.009}$ \\
\hline Lop 0.5 & $\mathrm{~TB}^{0.602}$ & $\mathrm{~TB}^{0.347}$ & $\mathrm{~TB}^{0.117}$ & - & $\mathrm{B}^{0.028}$ & $\mathrm{~B}^{0.016}$ & $\mathrm{~TB}^{0.076}$ & $\mathrm{~B}^{0.009}$ \\
\hline Lop 1 & $\mathrm{~B}^{0.009}$ & $\mathrm{~B}^{0.009}$ & $\mathrm{~B}^{0.028}$ & $\mathrm{~B}^{0.028}$ & - & $\mathrm{TB}^{0.465}$ & $\mathrm{~TB}^{0.076}$ & $\mathrm{~B}^{0.009}$ \\
\hline Lop 2 & $\mathrm{~B}^{0.016}$ & $\mathrm{~B}^{0.009}$ & $\mathrm{~B}^{0.028}$ & $\mathrm{~B}^{0.016}$ & $\mathrm{~TB}^{0.465}$ & - & $\mathrm{B}^{0.047}$ & $\mathrm{~B}^{0.009}$ \\
\hline Normal & $\mathrm{B}^{0.028}$ & $\mathrm{~B}^{0.016}$ & $\mathrm{~TB}^{0.347}$ & $\mathrm{~TB}^{0.076}$ & $\mathrm{~TB}^{0.076}$ & $\mathrm{~B}^{0.047}$ & - & $\begin{array}{l}\text { B } \\
0.009\end{array}$ \\
\hline $\mathrm{K}(-)$ & $\mathrm{B}^{0.009}$ & $\mathrm{~B}^{0.009}$ & $\mathrm{~B}^{0.009}$ & $\mathrm{~B}^{0.009}$ & $\mathrm{~B}^{0.009}$ & $\mathrm{~B}^{0.009}$ & $\mathrm{~B}^{0.009}$ & - \\
\hline
\end{tabular}

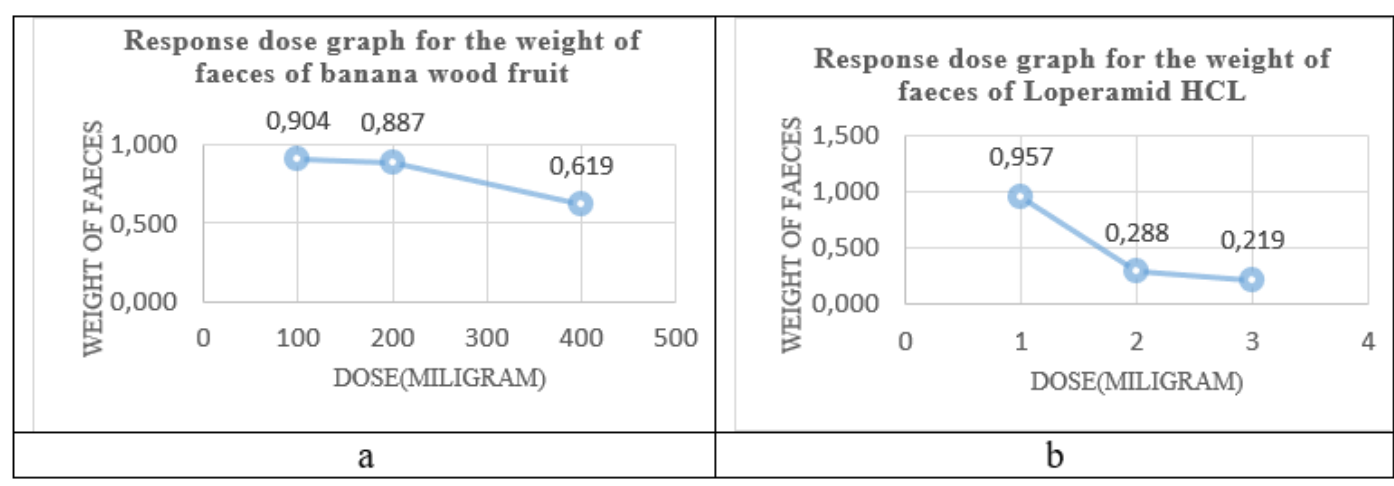

Fig. 3. Graph of the response dose weight of fecal of unripe wooden banana extract (a) and loperamide HCL (b).

\section{Antidiarrheal test for fecal weight parameters}

Descriptively, it can be concluded that the highest average fecal weight was the negative control group (CMC-Na) which was equal to $2.2000 \mathrm{~g}$. The lowest average fecal weight was Loperamid HCL group with a dose of $2 \mathrm{mg} / \mathrm{kgBW}$, which was equal to $0.2195 \mathrm{~g}$ of fecal weight of Kruskal Wallis test results was obtained sig value $<0.05$, so it can be concluded that there were differences between treatments, so it can be concluded that the average fecal weight in the eight treatment groups differed significantly.

From that data, it can be inferred that the ethanol extract of unripe wooden banana (Musa paradisiaca L.) could reduce the weight of fecal compared to the normal mice 
group, but it was still smaller compared to Loperamid HCL. From the three doses of ethanol extract of unripe wooden banana (Musa paradisiaca L.) showed that the greater the dose given, the smaller the $f$ weight of fecal of diarrhea.

\section{Antidiarrheal test for defecation parameters frequency}

Those could be concluded that the average frequency of the highest defecation was the negative control group (CMC-Na) that was equal to 30.60. The lowest average frequency was Loperamid HCL group with a dose of 1 $\mathrm{mg} / \mathrm{kg} \mathrm{BW}$ which was equal to 4.8 . The frequency of defecation Kruskal Wallis test results was obtained sig value $<0.05$, so it can be concluded that there were differences between treatments. Thus, it can be concluded that the average frequency of defecation in the eight treatment groups differed significantly. From that data, it could be said that the ethanol extract of unripe wooden banana (Musa paradisiaca L.) could reduce fecal weight compared to normal mice group, but was still small compared to Loperamid HCL. From the three doses of ethanol extract of unripe wooden banana (Musa paradisiaca L.), it showed that the greater the dose given, the smaller the frequency of defecation.

Table 5. Data on the average frequency of defecation of mice in each treatment group (gram)

\begin{tabular}{ccccccccc}
\hline Inducer & $\begin{array}{c}\text { Extract } \\
100\end{array}$ & $\begin{array}{c}\text { Extract } \\
200\end{array}$ & $\begin{array}{c}\text { Extract } \\
400\end{array}$ & $\begin{array}{c}\text { Extract } \\
0.5\end{array}$ & Lop 1 & Lop 2 & $\begin{array}{c}\text { Control } \\
\text { group }\end{array}$ & $\begin{array}{c}\text { Negative } \\
\text { control }\end{array}$ \\
\hline Escherichia & 24 & 13 & 17 & 22 & 1 & 14 & 22 & 22 \\
coli & 18 & 11 & 18 & 30 & 8 & 3 & 26 & 36 \\
& 18 & 18 & 19 & 23 & 4 & 2 & 25 & 42 \\
& 31 & 20 & 14 & 13 & 9 & 2 & 18 & 32 \\
& 16 & 15 & 14 & 9 & 2 & 6 & 21 & 21 \\
Average & 21.40 & 15.40 & 16.40 & 19.40 & 4.8 & 5.40 & 22.4 & 30.60 \\
\pm & \pm & \pm & \pm & \pm & \pm & \pm & \pm & \pm \\
SD & 6.148 & 3.647 & 1.030 & 3.750 & 1.594 & 2.272 & 1.435 & 4.045 \\
\hline
\end{tabular}

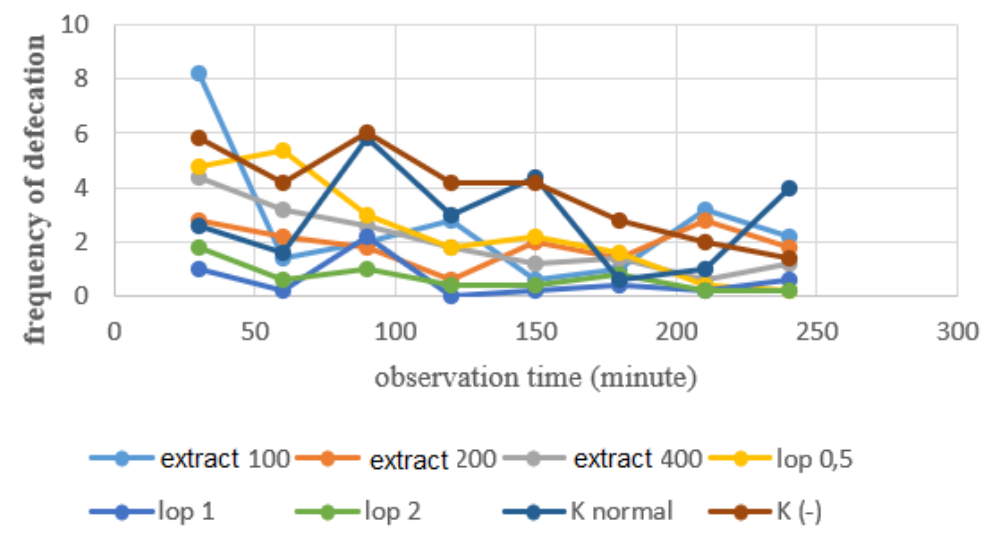

Fig. 4. Summary of the average graph of the frequency of defecation of mice in each treatment group.

Table 6. Mann-Whitney test results frequency of defecation between treatment groups

\begin{tabular}{|c|c|c|c|c|c|c|c|c|}
\hline & $\begin{array}{c}\text { Extract } \\
100\end{array}$ & $\begin{array}{c}\text { Extract } \\
200\end{array}$ & $\begin{array}{c}\text { Extract } \\
400\end{array}$ & Lop 0.5 & Lop 1 & Lop 2 & Normal & $\mathrm{K}(-)$ \\
\hline Extract 100 & - & $\mathrm{TB}^{0.047}$ & $\mathrm{~TB}^{0.246}$ & $\mathrm{~TB}^{0.754}$ & $\mathrm{~B}^{0.009}$ & $\mathrm{~B}^{0.009}$ & $\mathrm{~TB}^{0.402}$ & $\mathrm{~TB}^{0.076}$ \\
\hline Extract 200 & $\mathrm{~B}^{0.047}$ & - & $\mathrm{TB}^{0.399}$ & $\mathrm{~TB}^{0.401}$ & $\mathrm{~B}^{0.009}$ & $\mathrm{~B}^{0.027}$ & $\mathrm{~B}^{0.016}$ & $\mathrm{~B}^{0.009}$ \\
\hline Extract 400 & $\mathrm{~TB}^{0.246}$ & $\mathrm{~TB}^{0.399}$ & - & $\mathrm{TB}^{0.600}$ & $\mathrm{~B}^{0.009}$ & $\mathrm{~B}^{0.015}$ & $\mathrm{~B}^{0.021}$ & $\mathrm{~B}^{0.009}$ \\
\hline Lop 0.5 & $\mathrm{~TB}^{0.754}$ & $\mathrm{~TB}^{0.401}$ & $\mathrm{~TB}^{0.600}$ & - & $\mathrm{B}^{0.012}$ & $\mathrm{~B}^{0.028}$ & $\mathrm{~TB}^{0.675}$ & $\mathrm{~B}^{0.009}$ \\
\hline Lop 1 & $\mathrm{~B}^{0.009}$ & $\mathrm{~B}^{0.009}$ & $\mathrm{~B}^{0.009}$ & $\mathrm{~B}^{0.012}$ & - & $\mathrm{TB}^{0.916}$ & $\mathrm{~B}^{0.009}$ & $\mathrm{~B}^{0.009}$ \\
\hline Lop 2 & $\mathrm{~B}^{0.009}$ & $\mathrm{~B}^{0.027}$ & $\mathrm{~B}^{0.015}$ & $\mathrm{~B}^{0.028}$ & $\mathrm{~TB}^{0.916}$ & - & $\mathrm{B}^{0.009}$ & $\mathrm{~B}^{0.009}$ \\
\hline Normal & $\mathrm{TB}^{0.402}$ & $\mathrm{~B}^{0.016}$ & $\mathrm{~B}^{0.021}$ & $\mathrm{~TB}^{0.675}$ & $\mathrm{~B}^{0.009}$ & $\mathrm{~B}^{0.009}$ & - & $\mathrm{TB}^{0.172}$ \\
\hline $\mathrm{K}(-)$ & $\mathrm{TB}^{0.076}$ & $\mathrm{~B}^{0.009}$ & $\mathrm{~B}^{0.009}$ & $\mathrm{~B}^{0.009}$ & $\mathrm{~B}^{0.009}$ & $\mathrm{~B}^{0.009}$ & $\mathrm{~TB}^{0.172}$ & - \\
\hline
\end{tabular}

Description: B: significant TB: not significant 


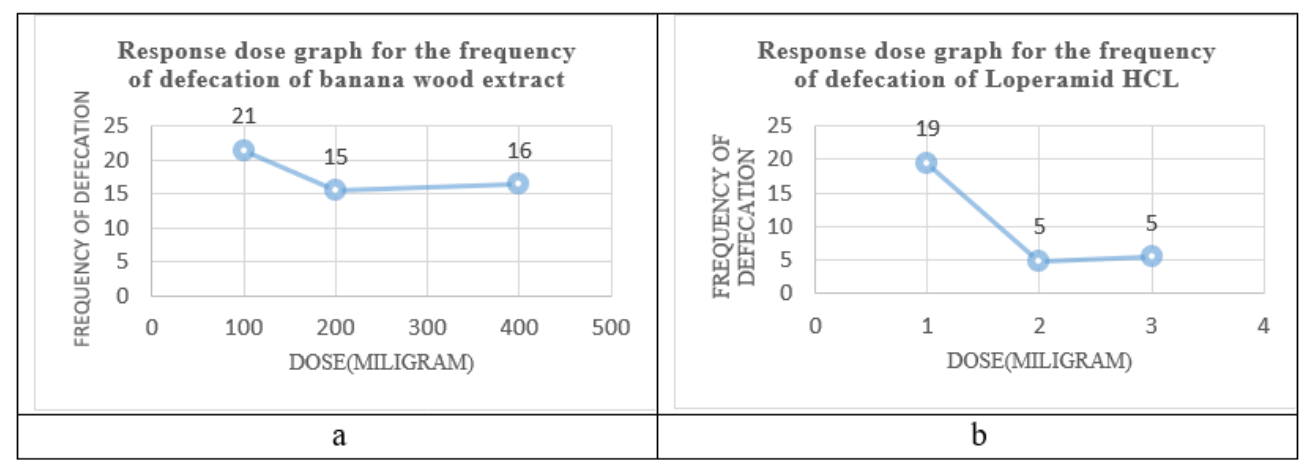

Fig. 5. Response dose frequency of unripe wooden banana (a) and loperamide $\mathrm{HCl}$ (b).

Table 7. Data on fecal consistency in each treatment group

\begin{tabular}{lccccc}
\hline No & Treatment groups & $\begin{array}{c}\text { No } \\
\text { defecation } \\
(4)\end{array}$ & solid (3) & soft (2) & liquid(1) \\
\hline 1 & Extract dose $100 \mathrm{mg} / \mathrm{kg} \mathrm{BW}$ & 1 & 4 & 0 & 0 \\
2 & Extract dose $200 \mathrm{mg} / \mathrm{kg} \mathrm{BW}$ & 1 & 4 & 0 & 0 \\
3 & Extract dose 400 mg/kg BW & 2 & 3 & 0 & 0 \\
4 & Loperamid HCL 0,5 mg/kg BW & 4 & 1 & 0 & 0 \\
5 & Loperamid HCL 1 mg/kg BW & 3 & 2 & 0 & 0 \\
6 & Loperamid HCL 2 mg/kg BW & 4 & 1 & 0 & 0 \\
7 & Control group & 2 & 3 & 0 & 0 \\
8 & Negative group & 0 & 0 & 1 & 4 \\
\hline
\end{tabular}

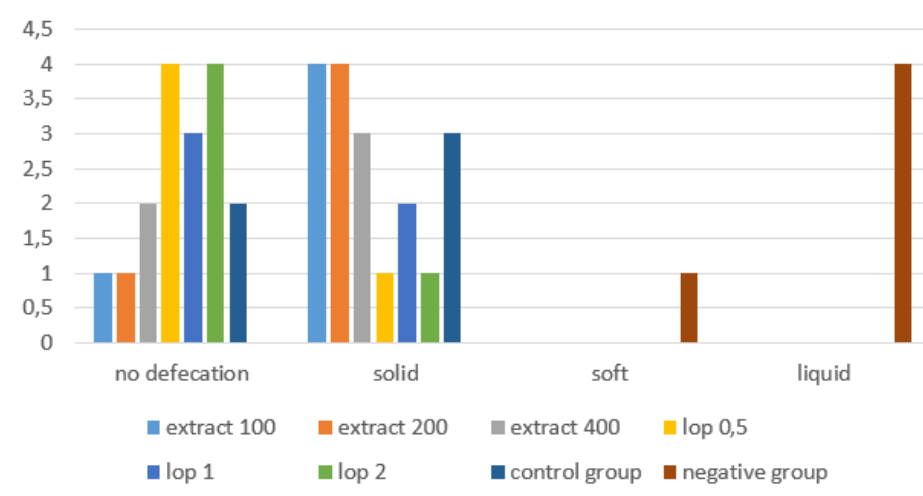

Figure 6. Fecal consistency in each treatment group.

Table 8 . The results of the Mann-Whitney test of fecal consistency between treatment groups

\begin{tabular}{lllllllll}
\hline & $\begin{array}{c}\text { Extract } \\
100\end{array}$ & $\begin{array}{c}\text { Extract } \\
200\end{array}$ & $\begin{array}{c}\text { Extract } \\
400\end{array}$ & \multicolumn{1}{c}{ Lop 0.5 } & Lop 1 & Lop 2 & Normal & K(-) \\
\hline Extract 100 & - & $\mathrm{TB}^{1.000}$ & $\mathrm{~TB}^{0.513}$ & $\mathrm{~TB}^{0.072}$ & $\mathrm{~TB}^{0.221}$ & $\mathrm{~TB}^{0.072}$ & $\mathrm{~TB}^{0.513}$ & $\mathrm{~B}^{0.005}$ \\
Extract 200 & $\mathrm{TB}^{1.000}$ & - & $\mathrm{TB}^{0.513}$ & $\mathrm{~TB}^{0.072}$ & $\mathrm{~TB}^{0.221}$ & $\mathrm{~TB}^{0.072}$ & $\mathrm{~TB}^{0.513}$ & $\mathrm{~B}^{0.005}$ \\
Extract 400 & $\mathrm{TB}^{0.513}$ & $\mathrm{~TB}^{0.513}$ & - & $\mathrm{TB}^{0.221}$ & $\mathrm{~TB}^{0.549}$ & $\mathrm{~TB}^{0.221}$ & $\mathrm{~TB}^{1.000}$ & $\mathrm{~B}^{0.006}$ \\
Lop 0.5 & $\mathrm{TB}^{0.072}$ & $\mathrm{~TB}^{0.072}$ & $\mathrm{~TB}^{0.221}$ & - & $\mathrm{TB}^{0.513}$ & $\mathrm{~TB}^{1.000}$ & $\mathrm{~TB}^{0.221}$ & $\mathrm{~B}^{0.005}$ \\
Lop1 & $\mathrm{TB}^{0.221}$ & $\mathrm{~TB}^{0.221}$ & $\mathrm{~TB}^{0.549}$ & $\mathrm{~TB}^{0.513}$ & - & $\mathrm{TB}^{0.513}$ & $\mathrm{~TB}^{0.549}$ & $\mathrm{~B}^{0.006}$ \\
Lop 2 & $\mathrm{B}^{0.072}$ & $\mathrm{~B}^{0.072}$ & $\mathrm{~TB}^{0.221}$ & $\mathrm{~TB}^{1.000}$ & $\mathrm{~TB}^{0.513}$ & - & $\mathrm{TB}^{0.221}$ & $\mathrm{~B}^{0.005}$ \\
Normal & $\mathrm{TB}^{0.513}$ & $\mathrm{~TB}^{0.513}$ & $\mathrm{~TB}^{1.000}$ & $\mathrm{~TB}^{0.221}$ & $\mathrm{~TB}^{0.549}$ & $\mathrm{~TB}^{0.221}$ & - & $\mathrm{B}^{0.006}$ \\
K(-) & $\mathrm{B}^{0.005}$ & $\mathrm{~B}^{0.005}$ & $\mathrm{~B}^{0.006}$ & $\mathrm{~B}^{0.005}$ & $\mathrm{~B}^{0.006}$ & $\mathrm{~B}^{0.005}$ & $\mathrm{~B}^{0.006}$ & - \\
\hline
\end{tabular}

Description: B: significant TB: not significant 


\section{Antidiarrheal test for fecal consistency parameters}

It can be concluded descriptively that there was a change in fecal consistency from the consistency of liquid or soft fecal to solid. The Kruskal Wallis test results was obtained sig values $<0.05$, so there were differences between samples. From these data it can be concluded that the fecal consistency of the eight groups' samples differed significantly. From the data above, it can be said that the ethanol extract of unripe wooden banana (Musa paradisiaca L.) at a dose of $100 \mathrm{mg} / \mathrm{kg}$ BW had made a change in consistency from soft or liquid to solid.

In Figure 6 showed that the results of determining the consistency of fecal were done by looking at the shape of the fecal that occurs that can be categorized into 4 groups; not defecating, solid, soft and liquid. From the observation of fecal consistency, all groups experienced liquid fecal at the onset of diarrhea after which changes in fecal consistency became normal (solid) compared to negative controls with fecal/fluid fecal consistency.

\section{DISCUSSION}

The test animals used in this study were male white mice (Balb-C). White mice were a type of mammal that had almost anatomical and physiological structures resembling humans. The reason of the use of male mice was that being considered not to affect much physically. Physical influences that could interfere with observations in this research process were pregnancy, so that the use of female mice was avoided. Age of mice 23 months, because at this age mice were considered adults so that their organs were able to work optimally (Rahmawati \& Fajaryanti 2017).

The positive control of diarrhea medication used was Loperamid HCL. Loperamid HCL was the most appropriate opioid for local effects on the intestine because it did not penetrate the brain. Therefore, Loperamid HCL only had a slight central effect and did not cause dependence. This substance was able to normalize the balance of restoration of mucous cells, which was to restore cells that were in a state of hyper secretion to a normal restoration state. The administration of the test solution was carried out poorly, which was the administration of the drug in the form of suspense to the test animals carried out by the aid of a needle with a blunt tip (ball shape/sonde) (Tjay \& Rahardja 2003).

Escherichia coli bacteria attack adult erythrocytes in the small intestine. Infection in erythrocytes causes lysis cells (rupture) by disrupting the absorption of nutrients and pushing water into the intestinal lumen through an osmotic mechanism. Diarrhea caused by bacteria occurs due to cell invasion and epithelial damage due to enteropathogenic agents which cause the accumulation of osmos was driven endoluminal fluid by unabsorbed nutrients (Yu et al 2017).

Ethanol extract of unripe wooden banana (Musa paradisiaca $L$.) contains active substances in the form of tannins, alkaloids and saponins. Tannins works as an astringent that works by shrinking the intestine so that it decreases smooth muscle contraction. This condition can ultimately reduce diarrhea.

Tannin can damage protein into tanat protein. This protein makes the intestinal mucosa more resistant, which can reduce excretion of water into the intestinal lumen. According to Arika (2018) the chelating properties of tannin have a spasmolytic effect, which can shrink the intestine so that intestinal peristaltic motion was reduced and can precipitate proteins on the intestinal surface. The properties of tannin astringent will make the small intestine more resistant to the stimulation of compounds that cause diarrhea (Arika 2018).

Alkaloids were heterocyclic nitrogen compounds, which were known to have antimicrobial activity. According to Harborne (1987) alkaloids can interfere with the formation of peptidoglycan constituents in bacterial cells, thus causing loss of bacterial cell wall function as an osmotic pressure protector. This causes bacterial cells to be sensitive to osmotic pressure, the presence of high osmotic pressure in bacterial cells will cause lysis of these bacterial cells (Harborne 1987).

Mufti et al (2017) stated that saponins were able to inhibit bacterial growth by inhibiting protein synthesis and reducing the surface tension of bacterial cells resulting in leakage. Saponins have a membraneolytic aglycone component which can cause a decrease in surface tension of bacterial cell walls. After the surface tension of the bacterial cell wall decreases, saponins form a complex with sterols which causes the formation of a single ion channel. Single ion channel causes cell membrane instability which inhibits enzyme activity in ion transport which plays a role in bacterial life. The decreasing surface tension of bacterial cell walls can also cause cell leakage so that intracellular compounds emerge. This causes inhibited bacterial cell growth. In this study the bananas used were raw and fresh, because empirically the antidiarrheal use of banana wood in Senduro, Lumajang, East Java, Indonesia was used in conditions that were still raw and fresh. According to Hanani (2015) the efficacy of tannin as an antidiarrheal 
in bananas was mostly on unripe wooden bananas and will decrease in ripe bananas.

Ethanol extract of unripe wooden banana (Musa paradisiaca L.) dose of $100 \mathrm{mg} / \mathrm{kg} \mathrm{BW}$ can reduce the frequency of defecation to 18.75 times, fecal weight to $0.7907 \mathrm{~g}$ and fecal consistency to solid. The use of different doses of administration will affect the strength of the test material in suppressing diarrhea. The higher the dose given, the greater the antidiarrheal effect produced by the dose. Ethanol extract of unripe wooden banana (Musa paradisiaca L.) dose of $100 \mathrm{mg} / \mathrm{kg} \mathrm{BW}$ was an effective dose in providing antidiarrheal effects because the administration of ethanol extract of unripe wooden banana (Musa paradisiaca L.) dose of 100 $\mathrm{mg} / \mathrm{kg}$ BW had changed the consistency to solid accompanied by a reduction frequency of defecation and fecal weight, but the antidiarrheal effect was still small compared to Loperamid HCL. The results of the Ningsih (2010) study also showed that the phytochemical test results of the ethanol extract of unripe wooden banana (Musa paradisiaca) showed that the positive content of tannin had antidiarrheal activity induced by Oleum Ricini at a dose of $100 \mathrm{mg} / \mathrm{kg} \mathrm{BW}$. The results of previous studies support this study that the ethanol extract of banana wood fruit had antidiarrheal activity at an effective dose of $100 \mathrm{mg} / \mathrm{kg}$ $\mathrm{BW}$. The difference in the previous research was that what diarrhea induction was used. In a previous study diarrhea induction used was Oleum Ricini and diarrhea induction used by researchers now was the bacterium Escherichia coli. The results of this further study supported that the ethanol extract of unripe wooden banana can be used as an alternative treatment for specific diarrhea (diarrhea caused by bacteria) and nonspecific diarrhea (diarrhea caused by oleum ricini), besides that the results of this study can be used as a baswas for development of antidiarrheal traditional medicine therapy and as an alternative treatment for health to treat diarrhea (Rianto et al 2015).

\section{CONCLUSION}

Based on the observation of the frequency of defecation, fecal weight and fecal consistency, the ethanol extract of unripe wooden banana doses of 100, 200 and 400 $\mathrm{mg} / \mathrm{kg} \mathrm{BW}$ had antidiarrheal effects compared to the negative control and control groups and the $400 \mathrm{mg} / \mathrm{kg}$ BW had the best antidiarrheal effect which was with a protection method induced by Escherichia coli bacteria but its effectiveness was not as good as Loperamide HCL. The ethanol extract of unripe wooden banana with a dose of $100 \mathrm{mg} / \mathrm{kg} \mathrm{BW}$ was an effective dose of therapy because at a dose of $100 \mathrm{mg} / \mathrm{kg} \mathrm{BW}$, it had been effective in reducing the frequency of defecation, fecal weight and there had been a change in fecal consistency.

\section{REFERENCES}

Arika F (2018). Uji aktivitas antidiare ekstrak etanol daun situduh langit (Erigeron sumatrensis Retz.) terhadap tikus jantan dengan metode transit intestinal. An undergraduate thesis. Medan, Universitas Sumatera Utara

Dalimartha S (2005). Tanaman obat di lingkungan sekitar. Jakarta, Penerbit Puspa Swara

Hanani E, 2015. Analisis Fitokimia. Jakarta: Penerbit buku kedokteran EGC.

Harborne J (1987). Metode fitokimia: penentuan cara modern menganalisis tumbuhan. Bandung, ITB

Mufti N, Bahar E, Arisanti D (2017). Uji daya hambat ekstrak daun sawo terhadap bakteri Escherichia coli secara in vitro. 6, 289-294

Ningsih AW (2010). Uji efek antidiare ekstrak buah pisang (Musa paradisiaca) pada mencit (Mus musculus) jantan galur balb-c. An undergraduate thesis. Jember, Universitas Jember

Rahmawati I, Fajaryanti N (2017). Uji aktivitas infusa tanaman anting-anting (Acalyphus australis Linn) sebgai obat diare pada mencit putih (Mus musculus) jantan yang terpapar oleum ricini. Jurnal Farmasetis 6, 21-24

Rianto L, Handayani IA, Septiyani A (2015). Uji aktivitas ekstrak etanol $96 \%$ biji srikaya (Annona squamosa L.) sebagai antidiare yang disebabkan oleh bakteri $S$ higella dysenteriae dengan metode difusi cakram. Jurnal Ilmiah Manuntung 1, 181-186

Tjay TH, Rahardja K (2003). Obat-obat penting. 4th Ed. Jakarta, Departemen Kesehatan RI

Yu J, Zhang Y, Song X, et al (2017). Effect of modified pulsatilla powder on enterotoxigenic Escherichia coli O101-induced diarrhea in mice. Hindawi, 1-11 